\title{
Nutraceuticals in Hypercholesterolemic children
}

\author{
Paola Cagliero, Giulia Calosso, Patrizia Brunatti, Ornella Guardamagna* \\ Department of Health and Pediatric Science, University of Turin, Turin, Italy; \\ *Corresponding Author: ornella.guardamagna@unito.it
}

Received 16 May 2013; revised 17 June 2013; accepted 30 June 2013

Copyright (C) 2013 Paola Cagliero et al. This is an open access article distributed under the Creative Commons Attribution License, which permits unrestricted use, distribution, and reproduction in any medium, provided the original work is properly cited.

\begin{abstract}
Hypercholesterolemia is associated with the atherosclerotic process and cardiovascular disease from childhood, thus introducing the need of an early prevention. The dietary approach is the treatment cornerstone but sometimes is unsuccessful to reach the lipoprotein optimal target. Furthermore, drugs like statins have limited use in childhood as their administration is limited to high risk children. The effects of nutraceuticals are known in adults and considered useful in children to overcome this therapy gap. In the present paper a review of pediatric experiences from fiber, phytosterols and RYR handing out is considered.
\end{abstract}

Keywords: Hypercholesterolemia; Child; Dietary Supplement; Fiber; Phytosterols; Red Yeast Rice; Probiotics

\section{INTRODUCTION}

The atherosclerotic cardiovascular disease (CVD) is the first cause of death in western countries. It has a multifactorial genesis and it is caused by different risk factors, changeable (dyslipidemia, hypertension, diabetes, smocking, obesity, physical inactivity) or not (age, male sex, genetic predisposition). Atherosclerotic process is proved to start since childhood, so it is important to discover precociously children affected by dyslipidemia and to start a follow up as well as therapeutic plan [1]. Dietary modification is the cornerstone of the management of these affected children. The Expert Panel on Blood Cholesterol Levels in Children and Adolescents recommends a dietary intervention in two steps, the Child-1 and the Child-2 diets [2].

The Child-1 diet calls for an intake of total fat and of saturated fat less than $30 \%$ and $10 \%$ of total calories respectively, and of dietary cholesterol $<300 \mathrm{mg}$ per day. If cholesterol reduction is not reached after a minimum of 3 months on this dietary approach, the child continues with the Child-2 diet (reduction of saturated fat $<7 \%$ and of dietary cholesterol $<200 \mathrm{mg}$ per day) [2]. This dietary intervention has been proven to be safe and effective in decreasing total cholesterol (TC) and Low-Density Lipoprotein-Cholesterol (LDL-C) but, even with good compliance, the dietary modification gives a not satisfying reduction of cholesterol concentrations [3]. Lipid-lowering drugs have been tolerated in short and medium terms, but long terms effects are still questionable. As this reason drug delivery is limited to high risk children. To overcome limits related to insufficient dietary approach and drug restriction, nutraceuticals can be considered. Nutraceutical is a food or a part of it, with beneficial effects on human system, which improves our health and well-being and prevents or treats a disease [4]. This group includes many active principles and paediatrics experiences, including up to now fiber, phytosterol and RYR.

\section{FIBER}

\subsection{Definition and Recommended Doses}

A generally accepted definition of fiber does not exist and the most common is based on its action in the gastrointestinal tract: "the remains of cell wall that resists to the hydrolysis by human digestive enzymes". The dietary fiber is an extremely complex mixture of different polysaccharides (cellulose, pectins, mucilages, galactomannans, $\beta$ glucans). These components are divided in soluble and insoluble and both are present in most of vegetable foods (cereals, fruits) [5]. The recommended doses are not well-defined, but it is generally accepted that fiber is important for a healthy diet. The American Health Foundation suggests an intake of $5-10 \mathrm{~g} /$ die added to the children age for children older than 2 years old [6] and the American Academy of Pediatrics (AAP) Committee on Nutrition recommends an intake of $0.5 \mathrm{~g} / \mathrm{kg}$ body weight for children older than $2 \mathrm{y}$, gradually increased to reach the adult recommendation (25 - $35 \mathrm{~g} / \mathrm{d})$ during adolescence [7]. 


\subsection{Functions and Mechanisms of Action}

Dietary fiber is a relevant dietary component, with several health benefits in both adults and children. It promotes gastrointestinal function and helps to reduce the risk of cardiovascular diseases by decreasing serum TC and LDL-C concentrations: in particular, various studies proved that a Child-1 diet associated with 0.5 $\mathrm{g}$ /day of glucomannan reduces TC and LDL-C to $10 \%$ [8-10], and 6 gr of psyllium reduce TC of $16 \%-18 \%$ and LDL-C of $22 \%$ - 24\% [11-13]. Generally dietary fiber intake has no effect on High-Density Lipoprotein Cholesterol (HDL-C) or triglyceride (Tg) concentrations, but lowers serum insulin concentrations and reduces the risk of obesity and type 2 diabetes. There are a lot of mechanisms of actions: fiber binds bile acid or cholesterol to form the mixed micelles, increasing their excretion with faeces; by this way there is an improvement of LDL-C receptor expression so resulting in a LDL-C increased clearance. It seems also that fiber inhibits the hepatic synthesis of fatty acids as well as it increases the intestinal motility and improves the satiety $[14,15]$.

\subsection{Collateral Effects}

Increasing the consumption of fiber can arise some unpleasant collateral effects (gas formation, abdominal discomfort, diarrhea, nausea) caused by the bacterial fiber fermentation. Therefore fiber intake should be increased gradually and should be accompanied by liquids, so that the gut can adapt to the change. These collateral effects should disappear after 24 - 48 hours [5]. Furthermore, some data suggest that a diet rich in fiber could cause an inadequate statural growth and nutritional status. This observation was confirmed only in children who consumed a vegan or macrobiotic diet [15].

\subsection{Results}

The results of clinical trials are represented in Table 1.

These trials show how the use of glucomannan and psyllium influences the lipid profile. Results are very different in both situation, ranging from $-5 \%[8,16]$ to $-18 \%[9,13]$ for the TC and from $-6.8 \%[16]$ to $-24 \%$ [11] for the LDL-C. These variations could be related to study design differences including the subjects diagnosis and age variability, limited number of patients, different fiber dosages and treatment period. Generally with the administration of $0.5 \mathrm{~g}$ of glucomannan once a day for 9 weeks [9], until a maximum of 24 weeks of treatment twice a day [8], we can observe a significant reduction of TC and LDL-C levels. Comparing TC and LDL-C levels in these studies, similar results are obtained with a

Table 1. The effects of fiber supplementation on lipid profile in dyslipidemic children.

\begin{tabular}{|c|c|c|c|c|c|c|}
\hline $\begin{array}{c}\text { Number of } \\
\text { patient }\end{array}$ & $\begin{array}{l}\text { Age }(\mathrm{yr}) \\
\text { range }\end{array}$ & Diagnosis $^{*}$ & Nutraceutical & Results $^{* *}$ & Type of study & Reference \\
\hline 36 & $6-15$ & $\mathrm{HC}$ & $\begin{array}{l}\text { Glucomannan } 500 \text { mg, } 2 \\
\text { doses/die, } 24 \text { weeks }\end{array}$ & $\begin{array}{l}\text { TC }-5.1 \% \\
\text { LDL-C }-7.3 \% \% \\
\text { non-HDL-C }-7.2 \%,=\text { ApoB }\end{array}$ & $\begin{array}{l}\text { Double-blind, randomized, } \\
\text { placebo-controlled, } \\
\text { cross-over }\end{array}$ & [8] \\
\hline 40 & $0-14$ & $\begin{array}{l}\mathrm{HC}(18) \\
\text { FCHL(3) } \\
\text { FH(19) }\end{array}$ & $\begin{array}{l}\text { Glucomannan } 0.5 \text { gr, } 1 \\
\text { dose/die, } 9 \text { weeks }\end{array}$ & $\begin{array}{l}\text { TC }-18 \% \\
\text { LDL-C }-24 \% \\
\text { Tg }-10 \%\end{array}$ & Randomized, controlled & [9] \\
\hline 84 & $4-18$ & $\mathrm{HC}$ & $\begin{array}{l}\text { Glucomannan tables }(50 \% \\
\text { bran } 50 \% \text { pectin })\end{array}$ & $\begin{array}{l}\mathrm{TC}-15 \% \\
\downarrow \mathrm{ApoB} \\
\downarrow \mathrm{Tg}\end{array}$ & $\begin{array}{l}\text { Not randomized, not } \\
\text { controlled }\end{array}$ & {$[3]$} \\
\hline 531 & n.d. & $\begin{array}{l}\text { Primary } \\
\text { Dyslipidemia }\end{array}$ & Glucomannan & $\begin{array}{l}\mathrm{TC}-19.28 \mathrm{mg} / \mathrm{dl} \\
\mathrm{LDL}-\mathrm{C}-15.99 \mathrm{mg} / \mathrm{dl} \\
\mathrm{Tg}-11.08 \mathrm{mg} / \mathrm{dl} \\
\text { Body weight }-0.79 \mathrm{Kg}=\text { PAOS }\end{array}$ & Metanalysis & {$[10]$} \\
\hline 25 & $6-18$ & $\mathrm{HC}$ & $\begin{array}{l}\text { Psyllium } 3.2 \text { gr, } 2 \text { doses/die, } 26 \\
\text { weeks }\end{array}$ & $\begin{array}{l}\mathrm{TC}-5 \% \\
\text { LDL-C }-6.8 \%\end{array}$ & $\begin{array}{l}\text { Double-blind, controlled, } \\
\text { crossover }\end{array}$ & {$[16]$} \\
\hline 11 & $11-18$ & Borderline $\mathrm{HC}$ & $\begin{array}{l}\text { Psyllium } 25 \text { gr, } 1 \text { dose/die, } 3 \\
\text { weeks }\end{array}$ & $\mathrm{TC}-7 \%$ & Crossover & [12] \\
\hline 36 & $3-17$ & $\mathrm{HC}$ & $\begin{array}{l}\text { Psyllium } 5 \text { - } 10 \text { gr, } 1 \text { dose/die, } \\
32 \text { weeks }\end{array}$ & $\begin{array}{l}\mathrm{TC}-18 \% \\
\text { LDL-C }-23 \%\end{array}$ & n.d. & [13] \\
\hline 1062 & $0.8-9$ & Healthy & Fiber $1 \mathrm{gr}, 1$ dose/die & $\begin{array}{l}\mathrm{TC}-0.1332 \mathrm{mg} / \mathrm{dl} \\
\mathrm{LDL}-\mathrm{C}-0.0972 \mathrm{mg} / \mathrm{dl} \\
\text { nonHDL-C }-0.1242 \mathrm{mg} / \mathrm{dl} \\
\text { Apo A }-0.006 \mathrm{mg} / \mathrm{dl} \\
\text { Apo B }-0.15 \mathrm{mg} / \mathrm{dl}\end{array}$ & $\begin{array}{l}\text { Randomized, controlled, } \\
\text { prospective }\end{array}$ & {$[15]$} \\
\hline 20 & $5-17$ & $\mathrm{HC}$ & $\begin{array}{l}\text { Psyllium } 6 \text { gr, } 2 \text { doses/die, } 4 \text { - } \\
5 \text { weeks }\end{array}$ & $\mathrm{Tg}+26 \mathrm{mg} / \mathrm{dl}$ & $\begin{array}{l}\text { Double blind, randomized, } \\
\text { placebo controlled, } \\
\text { crossover }\end{array}$ & [17] \\
\hline
\end{tabular}

Legend: ${ }^{*}$ diagnosis as referred by authors; ${ }^{* *} \downarrow$ : reduction without referred values; HC: hypercholesterolemia; FH: familiar hypercholesterolemia; FCHL: familiar combined hyperlipidemia; n.d. not determined. 
long period treatment, maybe due to the reaching of a balance of the metabolism.

With the psyllium administration results are conflicting, since a dose of $12 \mathrm{~g}$ /day for 20 weeks gave no variations [17], while a dose of $6.4 \mathrm{~g}$ /day for 26 weeks gave a small, but significant reduction both of TC and LDL-C [16].

In these studies there are controversial results about the atherogenic factor Apolipoprotein B (ApoB): in fact in some trials it does not change [8] or it is not measured, and in others it is decreased $[3,15]$.

\section{PHYTOSTEROLS}

\subsection{Definition and Recommended Doses}

They are plant sterols structurally similar to cholesterol, the main difference being the presence of ethilic and methilic groups in the lateral chain. They are principally found in nuts, fruits, seeds and their oils. Phytosterols exist mainly in a free (sterol) and esterified (stanol) form: when incorporated as functional food ingredient, they are frequently esterified with a fatty acid ester to increase their solubility in the food matrix. They are available in different forms: added to cereals, margarines, milk and yoghurt. Foods enriched with fatty acid esters of plant sterols or stanols are well known for their cholesterol lowering effect. The latter is not transient, as shown in a study with a daily assumption of $2 \mathrm{~g}$ plant sterols or stanols into a healthy diet low in saturated fatty acids [18].

\subsection{Functions and Action Mechanisms}

A daily assumption of $1.5-2.5 \mathrm{~g}$ of phytosterols/ stanols, possibly at the main meal, reduces TC levels of $5 \%$ - 11\% [19,20] and LDL-C levels until 9\% - 17\% [2024], without modifying HDL-C and VLDL-C concentrations.

Phytosterols are incorporated in mixed micelles, then cross the intestinal brush border membrane, and are internalized in the enterocytes by Niemann-Pick C1-Like 1 Receptor (NPC1L1). Here most of them are immediately expelled by the ATP-Binding Cassette subfamily $\mathrm{G}$ member 5 and 8 (ABCG 5 and 8 ), and only $5 \%$ of them enters chylomicrons and reaches the liver. The hypolipidemic effects are releated to competition with cholesterol to form mixed micelles; production of insoluble complexes with cholesterol in the gut thus eliminated with faeces; competition for protein NPC1L1 and promotion of cholesterol elimination by ABCG5 e ABCG8 [18].

\subsection{Collateral Effects}

Phytosterols are safe, except for a condition: this is ascribable to patients affected by sitosterolaemia. The latter disease is characterized by high phytosterol levels, thus additional delivery resulting proatherogenic as they display premature and severe CVD.

Previously it was postulated, from population-based studies, that plant sterols could promote CVD, but findings from 17 studies involving 11182 subjects did not yield any evidence of this association [25]. For these reasons plant sterols can be considered safe, well-tollerated and effective also in pediatrics; the unique demonstrated collateral effect is a modest reduction of the absorption of beta-carotene, which does not influence the final level of vitamin A [26].

\subsection{Results}

Table 2 shows the results of the clinical trials.

There are less differences in the reduction of TC and LDL-C levels, ranging from $-5 \%$ to $11 \%$ for $\mathrm{TC}$ and from $9 \%$ to $17 \%$ for LDL-C.

With the administration of stanol/sterol enriched yoghurt [27-29] or only with plant sterols [19-24], we observe a reduction of TC and LDL-C levels, sometimes accompanied with an increasing of HDL-C concentrations [19] and a reduction of ApoB levels [29]. Dairy foods phytosteol added show the best results in improving lipid profile. Comparing these data with those regarding the fiber, we can appreciate a minor variability in the age range of the patients and in the doses of sterols or stanols administrated.

\section{RED YEAST RICE (MONACOLIN K)}

\subsection{Definition and Recommended Doses}

Fermented red rice is produced traditionally by fermenting washed and cooked rice with red wine mash, that gives it the common red-violet colour. Instead, the commercially prepared red yeast rice (RYR) extract is fermented during 9 days with a specific strain of red yeast (Monascus purpureus Went) at a temperature of $25^{\circ} \mathrm{C}$, and at a $\mathrm{pH}$ range of 5 to 6 . The rice is then airdried, pulverised and encapsulated into gel capsules [30]. Major components found in RYR extract are nine types of active compounds known as monacolins, showing the same composition of lovostatin, a widely used statin. This active component is equivalent to around $5 \mathrm{mg}$ in a $1.2 \mathrm{~g}$ dose of RYR [31].

\subsection{Functions and Mechanisms of Action}

It Is diffusely admitted that RYR has hypolipidemic effects: many studies about dyslipidemic adults reveal a reduction of TC, LDL-C and Tryglicerides [31-34]; controversial are the effects on HDL-C [31]. The unique trial, as far as we know, applied to children shows how a 
Table 2. Lipid profile changes after phytosterols therapy in affected children.

\begin{tabular}{|c|c|c|c|c|c|c|}
\hline $\begin{array}{c}\text { Number of } \\
\text { patient }\end{array}$ & $\begin{array}{l}\text { Age }(\mathrm{yr}) \\
\text { range }\end{array}$ & Diagnosis $^{*}$ & Nutraceutical & Results $^{* *}$ & Type of study & Reference \\
\hline 58 & $8-16$ & $\begin{array}{l}\text { FH (32) } \\
\text { FCHL (13) } \\
\text { UH (13) }\end{array}$ & $\begin{array}{l}\text { Yoghurt with phytosterols } 1.6 \text { - } \\
2 \text { gr, } 1 \text { dose/die, } 12 \text { weeks }\end{array}$ & $\begin{array}{l}\downarrow \text { TC } \\
\text { LDL-C }-10.7 \%(\mathrm{FH}),-14.2 \% \\
(\mathrm{FCH}), 16 \%(\mathrm{UH}) \\
\downarrow \text { ApoB }\end{array}$ & Open-label, intervention & [27] \\
\hline 42 & $7-12$ & FH & $\begin{array}{l}\text { Yoghurt with stanols } 2 \text { gr, } 1 \\
\text { dose/die, } 4 \text { weeks }\end{array}$ & $\begin{array}{l}\text { TC }-7.5 \% \\
\text { LDL-C }-9.2 \%\end{array}$ & $\begin{array}{l}\text { Double-blind, controlled, } \\
\text { crossover }\end{array}$ & [28] \\
\hline 38 & $7-12$ & FH & $\begin{array}{l}\text { Yoghurt with sterols } 1.6 \mathrm{gr}, 1 \\
\text { dose/die, } 16 \text { weeks }\end{array}$ & $\begin{array}{l}\text { TC }-7.4 \% \\
\text { LDL-C }-10.2 \% \\
\text { ApoB }-7.4 \%\end{array}$ & $\begin{array}{l}\text { Double-blind, randomized, } \\
\text { crossover }\end{array}$ & [29] \\
\hline 15 & $2-15$ & FH & $\begin{array}{l}\text { Margarine with stanols } 3 \mathrm{gr}, 1 \\
\text { dose/die, } 6 \text { weeks }\end{array}$ & $\begin{array}{l}\text { TC }-11 \% \\
\text { LDL-C }-15 \% \\
\uparrow \text { HDL-C }\end{array}$ & $\begin{array}{l}\text { Double-blind, controlled, } \\
\text { crossover }\end{array}$ & [19] \\
\hline 25 & $11-17$ & $\mathrm{HC}$ & $\begin{array}{l}\text { Stanols } 1.3 \mathrm{gr}, 1 \mathrm{dose} / \mathrm{die}, 16 \\
\text { weeks }\end{array}$ & $\begin{array}{l}\downarrow \mathrm{TC} \\
\text { LDL-C }-9 \%\end{array}$ & Not controlled & [21] \\
\hline 37 & $7-13$ & FH & $\begin{array}{l}\text { Sterols } 1.2 \mathrm{gr}, 1 \text { dose/die, } 26 \\
\text { weeks }\end{array}$ & $\begin{array}{l}\text { TC }-9.1 \% \\
\text { LDL-C }-11.4 \%\end{array}$ & $\begin{array}{l}\text { Open-label follow-up of previous } \\
\text { controlled cross-over design }\end{array}$ & [22] \\
\hline 41 & $5-12$ & $\mathrm{FH}$ & $\begin{array}{l}\text { Sterols } 2.3 \mathrm{gr}, 1 \text { dose } / \mathrm{die}, 4 \\
\text { weeks }\end{array}$ & $\begin{array}{l}\mathrm{TC}-11 \% \\
\text { LDL-C }-14 \%\end{array}$ & $\begin{array}{l}\text { Double-blind, placebo-controlled, } \\
\text { crossover }\end{array}$ & [23] \\
\hline 72 & 6 & Healthy & $\begin{array}{l}\text { Stanols } 1.6 \mathrm{gr}, 1 \mathrm{dose} / \mathrm{die}, 6 \\
\text { months }\end{array}$ & $\begin{array}{l}\mathrm{TC}-5 \% \\
\mathrm{LDL}-\mathrm{C}-7.5 \%\end{array}$ & $\begin{array}{l}\text { Double-blind, randomized, } \\
\text { placebo-controlled, cross-over, } \\
\text { prospective }\end{array}$ & [20] \\
\hline 7 & $5-11$ & FH & $\begin{array}{l}\text { Sterols } 2 \mathrm{gr}, 1 \text { dose/die, } 3 \\
\text { months }\end{array}$ & $\begin{array}{l}\downarrow \mathrm{TC} \\
\text { LDL-C }-17 \%\end{array}$ & Randomized, prospective & [24] \\
\hline
\end{tabular}

Legend: ${ }^{*}$ diagnosis as referred by authors. ${ }^{* *} \downarrow$ : reduction without values; HC: hypercholesterolemia; FH: familiar hypercholesterolemia; FCHL: familiar combined hyperlipidemia; UH: undefined hyperlipidemia.

daily treatment with $200 \mathrm{mg}$ of RYR added to $10 \mathrm{mg}$ of policosanols as long as 8 weeks gives a reduction of TC of $18.5 \%$, of LDL-C of $25.1 \%$ and ApoB of $25.3 \%$ [35].

It was recently established that RYR has hypolipidemic proprieties because it contains monacolin $\mathrm{K}$, which has similar effects and mechanisms of action of lovastatin: it acts by inhibiting the hydroxymetylglutarylCoA reductase (HMG-CoA reductase), the enzyme present in the hepatic cells that regulates the synthesis of cholesterol. Other mechanisms may involve the prevention of dietary cholesterol absorption and enhanced cholesterol clearance from circulation. It should be underlined that the hypolipidemic RYR effect cannot be accounted only to the HMG-CoA reductase inhibitors, as other components could be involved in lowering lipid profile. Besides plant sterols (h-sitosterol, campesterol, stigmasterol, saponin and sapogenin), isoflavones, selenium and zinc are suggested to act together.

Finally the amount of HMG-CoA reductase inhibitors present in a dose of $2.4 \mathrm{~g}$ of RYR have similar hypolipidemic effects as lovastatin $10-40 \mathrm{mg}$ dose [31].

\subsection{Collateral Effects}

Red yeast rice seems to be safe when compared with statins. The incidence of adverse side effects is fairly low and long-standing record whose efficacy and safety have been shown over time is available. In addition, there are no reported food or drug interactions, and it appears that it does not interact with renal and liver function. Anyway it should be taken into account the possibility of liver or muscle enzyme increase and the occurrence of rabdomyolisis was reported [36]. Other symptoms including allergy, heart burn, abdominal discomfort, flatulence and dizziness have been noticed. Limitations to explain the final efficacy, and possible limitations of RYR, concern the effects of other bioactive components, their functions and the consideration if effective enough to market as a drug. This latter consideration is important as it questions the purity and standardization of the product. It is unclear in almost all the reviewed studies whether the same fermentation process was used consistently, and why a specific strain of Monascus purpureus Went was chosen to produce red yeast rice. Perhaps other types of Monascus would yield products with different hypolipidemic abilities [31]. In addition, since there is not a standarddisation of the needed dose of the active component, it is possible to obtain different efficacy and toxicity. Monacolin $\mathrm{K}$ is chemically a statin so it is necessary when administrated to respect all carefulnesses and indications requested these drugs [37].

\subsection{Results}

A diet enriched with RYR has determined, in adults, an improvement of lipid profile demonstrating a significant reduction of TC, Tg, LDL [31-34], Apo B [34] and an HDL-C increase [31]. On this basis a cross-over, randomized trial, with a brand characterized by RYR and policosanol, was performed in hypercholesterolemic children, including FH $(\mathrm{n}=24)$ and FCHL $(\mathrm{n}=16)$ patients. Results were positive for efficacy showing a TC, 
LDL-C and Apo-B percentage reduction corresponding to $18.5 \%, 25.1 \%$ and $25.3 \%$ respectively. Further the nutraceutical resulted well tolerated and no adverse events or symptoms were reported [35].

\section{PROBIOTICS}

\subsection{Definition and Recommended Doses}

They are defined by the WHO as "live micro-organisms which, when administered in adequate amounts, confer a health benefit on the host" and are being examined for their efficacy in preventing or treating a host of diseases. Probiotic strains belong mostly to the genera Lacto-bacillus and Bifidobacterium [38].

\subsection{Functions and Mechanisms of Action}

Certain probiotic bacterial strains, besides preventing metabolic syndrome, reducing the duration of acute diarrhea and the risk of nosocomial diarrhea and rotavirus gastroenteritis, preventing sepsis and severe acute pancreatitis, they reduce lipid levels in hyperlipidemic patients [38].

Studies show that a daily assumption of probiotic reduces TC and LDL-C [39-41]. The yoghurt enriched with bile-salt hydrolase (BSH) producing probiotic strains (Lactobacillus acidofilus, L. casei, L. reuteri, Bifidobacterium longum) causes a reduction of TC, LDL-C, nonHDL-C and Apo B100 serum levels [42,43].

There are a number of mechanisms of action potentially involved in lowering cholesterol, and involve the intestine lumen, the liver and other organs. $\mathrm{BSH}$ is an enzyme only present in bacteria and is responsible for increasing bile acid deconjugation by hydrolysis of the amide bond, in the gut lumen. This mechanism increases levels of circulating deconjugated bile salts and decreases cholesterol absorption by enterocytes, due to a reduced capacity to form mixed micelles. These modifications may influence the farnesoid X receptor (FXR), a bile acid nuclear receptor that, through many steps, leads to the upregulation of ABCG5/G8 resulting in a decreased absorption and increased excretion of cholesterol. Finally BSH activity inhibits NPC1L1 so acting with a similar effect of plant sterols [44].

\subsection{Collateral Effects}

Collateral effects of probiotics are not yet well-defined, since trials are still in progress. This does not mean that collateral effects are irrelevant or missing, but that does not exist specific sperimental results about it. Among possible collateral effects, there are intolerance or allergy to metals and minerals present in the pharmaceutical. Not serious, but widespread, are the gastrointestinal symptoms: abdominal spasms, meteorism, flatulence and diarrhea [38].

For these reasons specific bacterial strains should be identified and used in probiotic preparation.

\subsection{Results}

Healthy $[39,41]$ and dyslipidemic $[40,42,43]$ adults took advantage from probiotic-enriched yoghurt. Results from double blind, randomized, placebo-controlled studies demonstrate a TC and LDL-C levels decrease ranging between $4.4 \%-9.1 \%$ and $5.4 \%-11.6 \%$ respectively. These reductions were considered statistically significant. As for children preliminary results from a controlled study conducted on primary affected hypercolesterolemic children confirmed data from adults (P. Cagliero, unpublished data).

\section{CONCLUSIONS}

All these studies show that, when the dietary intervention alone is not sufficient to reach acceptable lipid levels $\left(<90^{\circ}\right.$ percentile), nutraceutics could be considered for their efficacy and safety in paediatrics.

In particular, fiber is also proved to be useful in dyslipidemic children: satisfying results need to be obtained, simply increasing its intake with food, in daily diet. When this result could not be reached by this way some benefits come from added fiber.

A more significant reduction of lipoprotein levels is obtained by phytosterol administration, mainly added to dairy products. This dietary supplement resulted efficacy and safe also safe in children. Scientific studies provided enough evidences to the European Food Safety Authority (EFSA) that established the claim availability of phytosterols as supplementary food with hypocholesterolemic properties [45].

Regarding RYR effects, their effectiveness are abundantly confirmed in adults, while poor in children. However, it does not surprise the hypolipidemic action as ascribed to monacolin $\mathrm{K}$ that, acting as a statin, employs a pharmaceutical-like effect.

New directions for the near future could be represented by probiotics, which preliminary efficacy has been proven in adults while clinical trials in children are still in progress.

\section{REFERENCES}

[1] Landmesser, U., Hornig, B. and Drexler, H. (2004) Endothelial function: A critical determinant in atherosclerosis? Circulation, 109, 27-33. doi:10.1161/01.CIR.0000129501.88485.1f

[2] (2011) Expert panel on integrated guidelines for cardiovascular health and risk reduction in children and adolescents: Summary report. Pediatrics, 128, 213-256. doi:10.1542/peds.2009-2107C

[3] Sanchez-Bayle, M., Gonzalez-Requejo, A., Asensio-An- 
ton, J., Ruiz-Jarabo, C., Fernandez-Ruiz, M.L. and Baeza, J. (2001) The effect of fiber supplementation on lipid profile in children with hypercholesterolemia. Clinical Pediatrics, 40, 291-294.

doi:10.1177/000992280104000511

[4] Katan, M.B., Grundy, S.M., Jones, P., Law, M., Miettinen, T. and Paoletti, R. (2003) Efficacy and safety of plant stanols and sterols in the management of blood cholesterol levels. Mayo Clinic Proceeding, 78, 965-978.

[5] Subcommittee on the Tenth Edition of the Recommended Dietary Allowances, Food and Nutrition Board, Commission on Life Sciences, National Research Council (1989) Recommended dietary allowances. 10th Edition, Washington DC, 39-43.

[6] Williams, C.L., Bollella, M. and Wynder, E.L. (1995) A new recommendation for dietary fiber in childhood. $P e$ diatrics, 96, 985-988.

[7] American Academy of Pediatrics, Committee on Nutrition (1993) Carbohydrate and dietary fiber. In: Barness, L., Ed., Pediatric Nutrition Handbook, 3rd Edition, American Academy of Pediatrics, Elk Grove, 100-106.

[8] Guardamagna, O., Abello, F. and Visioli, F. (2013) Could dyslipidemic children benefit from glucomannan intake? Nutrition, in press. doi:10.1016/j.nut.2013.02.010

[9] Martino, F., Martino, E., Morrone, F., Carnevali, E., Forcone, R. and Niglio, T. (2005) Effect of dietary supplementation with glucomannan on plasma total cholesterol and low density lipoprotein cholesterol in hypercholesterolemic children. Nutrition Metabolism and Cardiovascular Diseases, 15, 174-180. doi:10.1016/i.numecd.2004.04.004

[10] Sood, N., Baker, W.L. and Coleman, C.I. (2008) Effect of glucomannan on plasma lipid and glucose concentrations, body weight, and blood pressure: systematic review and meta-analysis. American Journal of Clinical Nutrition, 88, 1167-1175.

[11] Williams, C.L., Bollella, M.C., Strobino, B.A., Boccia, L. and Campanaro, L. (1999) Plant stanol ester and bran fiber in childhood: Effects on lipids, stool weight and stool frequency in preschool children. Journal of American College of Nutrition, 18, 572-581. doi:10.1080/07315724.1999.10718891

[12] Taneja, A., Bhat, C.M., Arora, A. and Kaur, A.P. (1989) Effect of incorporation of isabgol husk in a low fibre diet on faecal excretion and serum levels of lipids in adolescent girls. European Journal of Clinical Nutrition, 43, 197-202.

[13] Glassman, M., Spark, A., Berezin, S., Schwarz, S., Medow, M. and Newman, L.J. (1990) Treatment of type IIa hyperlipidemia in childhood by a simplified American Heart Association diet and fiber supplementation. American Journal of Diseases of Children, 144, 973-976.

[14] Guardamagna, O., Baracco, V. and Abello, F. (2009) Le dislipidemie in pediatria. Johan \& Levi Editore, Milano, $1-143$.

[15] Ruottinen, S., Lagström, H.K., Niinikoski, H., Rönnemaa, T., Saarinen, M., Pahkala, K.A., Hakanen, M., Viikari, J.S. and Simell, O. (2010) Dietary fiber does not displace energy but is associated with decreased serum cholesterol concentrations in healthy children. The American Journal of Clinical Nutrition, 91, 651-661. doi:10.3945/ajen.2009.28461

[16] Davidson, M.H., Dugan, L.D., Burns, J.H., Sugimoto, D., Story, K. and Drennan, K. (1996) A psyllium enriched cereal for the treatment of hypercholesterolemia in children: A controlled, double-blind, crossover study. American Journal of Clinical Nutrition, 63, 96-102.

[17] Dennison, B.A. and Levine, D.M. (1993) Randomised, double blind, placebo controlled, two-period crossover clinical trial of psyllium fiber in children with hypercholesterolemia. The Journal of Pediatrics, 123, 24-29. doi:10.1016/S0022-3476(05)81532-X

[18] De Smet, E., Mensink, R.P. and Plat, J. (2012) Effects of plant sterols and stanols on intestinal cholesterol metabolism: Suggested mechanisms from past to present. Molecular Nutrition and Food Research, 56, 1058-1072. doi:10.1002/mnfr.201100722

[19] Gylling, H., Siimes, M.A. and Miettinen, T.A. (1995) Sitostanol ester margarine in dietary treatment of children with familial hypercholesterolemia. Journal of lipid researche, 36, 1807-1812.

[20] Tammi, A., Rönnemaa, T., Miettinen, T.A., Gylling, H., Rask-Nissilä, L., Viikari, J., Tuominen, J., Marniemi, J. and Simell, O. (2002) Effect of gender, ApoE phenotype and cholesterol-lowering by plant stanol esters in children: The STRIP study. Acta Paediatrica, 91, 1155-1162. doi:10.1111/j.1651-2227.2002.tb00121.x

[21] Garaiova, I., Muchová, J., Nagyová, Z., Mišl’anová, C., Oravec, S., Dukát, A., Wang, D., Plummer, S.F. and Duračková, Z. (2013) Effect of a plant sterol, fish oil and B vitamin combination in cardiovascular risk factors in hypercholesterolemic children and adolescent: A pilot study. Nutrition Journal, 8, 12-17.

[22] Amundsen, A.L., Ntanios, F., Put, N. and Ose, L. (2004) Long term compliance and changes in plasma lipids, plant sterols and carotenoids in children and parents with familial hypercholesterolemia consuming plant sterol ester enriched spread. European Journal of Clinical Nutrition, 58, 1612-1620. doi:10.1038/sj.ejen.1602015

[23] De Jongh, S., Vissers, M.N., Rol, P., Bakker, H.D., Kastelein, J.J. and Stroes, E.S. (2003) Plant sterols lower LDL-C without improving endothelial function in prepuberal children with familial hypercholesterolemia. Journal of Inherit Metabolic Disease, 26, 343-351. doi:10.1023/A:1025155002348

[24] Becker, M., Staab, D. and Von Bergmann, K. (1993) Treatment of severe familial hypercholesterolemia in childhood with sitostenol and sitostanol. Journal of Pediatrics, 122, 292-296. doi:10.1016/S0022-3476(06)80136-8

[25] Genser, B., Silbernagel, G., De Backer, G., Bruckert, E., Carmena, R., Chapman, M.J., Deanfield, J., Descamps, O.S., Rietzschel, E.R., Dias, K.C. and März, W. (2012) Plant sterols and cardiovascular disease: A systematic review and meta-analysis. European Heart Journal, 33, 444-451. doi:10.1093/eurheartj/ehr441

[26] Gylling, H., Hallikainen, M., Nissinen, M.J. and Miettinen, T.A. (2010) The effect of a very high daily plant stanol ester intake on serum lipids, carotenoids, and fatsoluble vitamins. Clinical Nutrition, 29, 112-118. 
doi:10.1016/j.clnu.2009.08.005

[27] Guardamagna, O., Abello, F., Baracco, V., Federici, G., Bertucci, P., Mozzi, A., Mannucci, L., Gnasso, A. and Cortese, C. (2011) Primary hyperlipidemias in children: Effect of plant sterol supplementation on plasma lipids and markers of cholesterol synthesis and absorption. Acta Diabetologica, 48, 127-133. doi:10.1007/s00592-010-0233-1

[28] Jakulj, L., Vissers, M.N., Rodenburg, J., Wiegman, A., Trip, M.D. and Kastelein, J.J. (2006) Plant stanols do not restore endothelial function in pre-puberal children with familial hypercholesterolemia despite reduction of LDLC levels. Journal of Pediatrics, 148, 495-500. doi:10.1016/j.jpeds.2005.11.023

[29] Amundsen, A.L., Ose, L., Nenseter, M.S. and Ntanios, F.Y. (2002) Plant sterol ester-enriched spread lowers plasma total and LDL cholesterol in children with familial hypercholesterolemia. The American Journal of Clinical Nutrition, 76, 338-344.

[30] Ma, J., Li, Y., Ye, Q., Li, J., Hua, Y., Ju, D., Zhang, D., Cooper, R. and Chang, M. (2000) Constituents of red yeast rice, a traditional Chinese food and medicine. Journal of Agricultural and Food Chemistry, 48, 5220-5225. doi:10.1021/if000338c

[31] Journoud, M. and Jones, P.J. (2004) Red yeast rice: A new hypolipidemic drug. Life Sciences, 74, 2675-2683. doi:10.1016/j.1fs.2003.10.018

[32] Wang, J., Lu, Z., Chi, J., Wang, W., Su, M., Kou, W., Yu, P., Yu, L., Chen, L., Zhu, J.S. and Chang, J. (1997) Multicenter clinical trial of the serum lipid-lowering effects of a Monascus purpureus (red yeast) rice preparation from traditional Chinese medicine. Current Therapeutic Research, 58, 964-978.

[33] Heber, D., Yip, I., Ashley, J.M., Elashoff, D.A., Elashoff, R.M. and Go, V.L. (1999) Cholesterol-lowering effects of a proprietary Chinese red-yeast-rice dietary supplement. American Journal of Clinical Nutrition, 69, 231-236.

[34] Lin, C.C., Li, T.C. and Lai, M.M. (2005) Efficacy and safety of Monascus purpureus went rice in subjects with hyperlipidemia. European Journal of Endocrinology, 153, 679-686. doi:10.1530/eje.1.02012

[35] Guardamagna, O., Abello, F., Baracco, V., Stasiowska, B. and Martino, F. (2011) The treatment of hypercholesterolemic children: Efficacy and safety of a combination of red yeast rice extract and policosanols. Nutrition, $\mathrm{Me}-$ tabolism \& Cardiovascular Diseases, 21, 424-429. doi:10.1016/j.numecd.2009.10.015

[36] Smith, D.J. and Olive, K.E. (2003) Chinese red rice-induced myopathy. Southern Medical Journal, 96, 1265-

\section{7. doi:10.1097/01.SMJ.0000100117.79718.DC}

[37] Yang, C.W. and Mousa, S.A. (2012) The effect of red yeast rice (Monascus purpureus) in dyslipidemia and other disorders. Complementary Therapies in Medicine, 20, 466-474. doi:10.1016/j.ctim.2012.07.004

[38] Jones, M.L., Tomaro-Duchesneau, C., Martoni, C.J. and Prakash, S. (2013) Cholesterol lowering with bile salt hydrolase-active probiotic bacteria, mechanism of action, clinical evidence, and future direction for heart health applications. Expert Opinion of Biological Therapy, 13, 631-642. doi:10.1517/14712598.2013.758706

[39] Schaafsma, G., Meuling, W.J., Van Dokkum, W. and Bouley, C. (1998) Effects of a milk product, fermented by Lactobacillus acidophilus and with fructo-oligosaccharides added, on blood lipids in male volunteers. European Journal of Clinical Nutrition, 52, 436-440. doi:10.1038/sj.ejen.1600583

[40] Bertolami, M.C., Faludi, A.A. and Batlouni, M. (1999) Evaluation of the effects of a new fermented milk product (Gaio) on primary hypercholesterolemia. European Journal of Clinical Nutrition, 53, 97-101. doi:10.1038/sj.ejen.1600683

[41] Agerbaek, M., Gerdes, L.U. and Richelsen, B. (1995) Hypocholesterolaemic effect of a new fermented milk product in healthy middle-aged men. European Journal of Clinical Nutrition, 49, 346-352.

[42] Jones, M.L., Martoni, C.J., Parent, M. and Prakash, S. (2011) Cholesterol-lowering efficacy of a microencapsulated bile salt hydrolase-active Lactobacillus reuteri NCIMB 30242 yoghurt formulation in hypercholesterolaemic adults. British Journal of Nutrition, 107, 15051513. doi:10.1017/S0007114511004703

[43] Jones, M.L., Martoni, C.J. and Prakash, S. (2012) Cholesterol lowering and inhibition of sterol absorption by Lactobacillus reuteri NCIMB 30242: A randomized controlled trial. European Journal of Clinical Nutrition, 66, 1234-1241. doi:10.1038/ejcn.2012.126

[44] Ooi, L.G., Ahmad, R., Yuen, K.H. and Liong, M.T. (2011) Lactobacillus acidophilus CHO-220 and inulin reduced plasma total cholesterol and low-density lipoprotein cholesterol via alteration of lipid transporters. Journal of Dairy Science, 93, 5048-5058. doi:10.3168/jds.2010-3311

[45] (2008) Scientific opinion of the panel on dietetic products nutrition and allergies on a request from unilever PLC/ $\mathrm{NV}$ on plant Sterols and lower/reduced blood cholesterol, reduced the risk of (coronary) heart disease. The EFSA Journal, 781, 1-12. 